\title{
Density Effects and Growth Analysis in Some Tropical Forest Plantations
}

\author{
Somchai THORANISORN Department of Biology, Faculty of Science, Osaka City University, \\ Sumiyoshi-ku Osaka 558, JAPAN \\ Pongsak SAHUNALU Department of Silviculture, Faculty of Forestry, Kasetsart University, \\ Bangkok 10903, Thailand \\ Kyoji YODA Department of Biology, Faculty of Science, Osaka City University, \\ Sumiyoshi-ku Osaka 558, JAPAN
}

\begin{abstract}
Effects of density on plant growth and self-thinning process were studied in tropical forest plantations of Melia azedarach and Azadirachta indica from one year-old to six year-old. The density levels were controlled by changing the initial tree number per area from 625 trees ha-1 $^{-1}$ to 40000 trees ha-1 and 157 trees ha $^{-1}$ to 40000 trees ha-1 for $M$. azedarach and $A$. indica, respectively. The density dependent mortality was remarkable in $M$. azedarach plantations. But it was not evident in $A$. indica plantations which had slow growth on very poor soil. The $w$ - $\rho$ relationship and $w-\rho$ trajectories were approximated by Hozumi's model. The coefficient values of the model were compared with those of former results from Eucalyptus camaldulensis and Pinus strobus. The $\beta$ value of the model for $M$. azedarach and $A$. indica differed from $3 / 2$ which expected from the Yoda's $3 / 2$ power law. This seemed to be due to the lack of severe death of individual trees in all plots during the period of the study. The growth of these two species followed the general logistic growth curve which was characterized by changing asymptotic tree size and intrinsic growth rate during the growth period. The lag time for both species was equal to zero. There was no distinct difference in maximum biological time between these species.
\end{abstract}

Key words : Azadirachta indica / density effect / growth analysis / Hozumi's model / Melia azedarach

Deforestation in the tropics has been expanding without detention, causing an imminent danger to the global environment. The depletion rate of natural tropical forests is approximately twelve million hectares per year (Whitmore, 1990). The major causes are due to the rapid population growth and increasing demands of forest products for various usages and of land for farming. The decrease of natural forests caused an increasing need for man-made forest establishment in many tropical countries (Brown et al., 1986). It was estimated that every nine hectares of destroyed closed forests in the tropics had been replaced by one hectare of forest plantation in 1980 (Lanly, 1982). The species used in such the plantation are usually screened from native or exotic florae based on the fascinating characteristics which will be expected in the new established stands. The establishment of man-made forests will have considerable values as tools for increasing the forest area and conserving the natural forests by acting as an important source of timber in the future and as a big sink of carbon dioxide in the global carbon cycle (Wadsworth, 1983; Evans, 1983 and Brown et al., 1986). In this context, there are many problems to be dissolved in tropical plantations, such as environmental and nutrient factors influencing growth either of indigenous or exotic trees in plantation, intraspecific competition of these plants in various planting density, pest control etc. The climatic factors influencing the productivity of tree plantations are numerous (Lugo et al., 
1988; etc.). The study of the dependence of tropical tree growth upon the growth factors are practically scanty. Among the growth factors, the planting space or tree density is a unique factor, which inhibits individual tree growth but increases stand yield, as already clarified by several studies in temperate regions (Ando, 1968; Hozumi, 1977; Shinozaki \& Kira, 1956). It has been freely adopted by foresters for most of tropical silviculture without concrete predict of future timber yield. In temperate silviculture, Ando (1968), Harms \& Langdon (1976) and Drew and Flewelling (1977) demonstrated effects of planting density on individual tree growth and subsequent stand yield. Among a few studies on this line in the tropics, Kongsangchai (1988) reported the effects of density on production of mangrove plantations in Thailand. In the preceding paper (Thoranisorn et al., 1990), effects of tree density on growth of trees and stand development with time were studied in Eucalyptus camaldulensis plantations. The characteristics of stand development and tree growth of this plantation could be explained by the coefficient values of Hozumi's model (1977).

In this study, the density effects on tree growth and stand development of two native species of Thailand, Melia azedarach Linn. and Azadirachta indica A. Juss var. siamensis Valeton were studied. The coefficient values of Hozumi's model for each species will be compared with those for E. camaldulensis and Pinus strobus (Hozumi, 1977). The results of this study are expected to extend the knowledges of tropical silviculturists and to assist forest ecologists for understanding the growth process of both species.

\section{STUDY SITES}

Experiments were conducted at the Ratchaburi Forest Experiment Station of the Royal Forest Department (RFD) for A. indica and at the Somdet Forest Plantation of the Forest Industry Organization (FIO) for M. azedarach from 1983 to 1989. The Ratchaburi Forest Experiment Station and the Somdet Forest Plantation will be called briefly as R-site and S-site, respectively. The R-site is located at Ratchaburi province, western part of the central region of Thailand $\left(13^{\circ} 35^{\prime} \mathrm{N}, 103^{\circ} 30^{\prime} \mathrm{E}\right)$. The original vegetation was dry dipterocarp forest which had been damaged by repeated cutting. Experiment plots were set up on a flat land at $35 \mathrm{~m}$ in altitude. Soils of this site are lateritic type composing of high percentage of heavy clay, original rock fragments and secondary formed irony gravel. The climate of the site is the driest among the other regions in Thailand. Mean annual rainfall and temperature are 1,054 $\mathrm{mm}$ and $28.7^{\circ} \mathrm{C}$, respectively. For the Somdet Forest Plantation, details of the study site were described in the previous paper (Thoranisorn et al., 1990).

\section{METHODS}

Six month-old seedlings of $M$. azedarach and $A$. indica were transplanted at experimental plots in a regular square pattern by six and eight levels of initial tree number per area, respectively, in June, 1983. The outline of the experiments is shown in Table 1. The abbreviations of plot name in the table were used for indicating the density levels. Fifty seedlings of each species were sampled before the planting and dried at $85^{\circ} \mathrm{C}$ in a oven for getting the initial dry weight of trees $\left(w_{0}\right)$. Tree size measurements were repeated every year in June or July 
Table 1. Outline of experiment at Somdet and Ratchaburi experimental sites.

\begin{tabular}{rccccc}
\hline $\begin{array}{l}\text { Plot } \\
\text { name }\end{array}$ & Plot size & $\begin{array}{c}\text { Initial } \\
\text { spacing } \\
(\mathrm{m} \times \mathrm{m})\end{array}$ & $\begin{array}{c}\text { Initial } \\
\text { density }\end{array}$ & $\begin{array}{c}\text { Number of } \\
\left(\text { trees ha }^{-1}\right)\end{array}$ & $\begin{array}{c}\text { Number of } \\
\text { trees plot }^{-1} \\
\text { measured } \\
\text { trees }\end{array}$ \\
\hline 400D & $30 \times 30$ & $0.50 \times 0.50$ & 40,000 & 3,600 & 1,600 \\
177D & $30 \times 30$ & $0.75 \times 0.75$ & 17,778 & 1,600 & 900 \\
100D & $30 \times 30$ & $1.00 \times 1.00$ & 10,000 & 900 & 484 \\
44D & $30 \times 30$ & $1.50 \times 1.50$ & 4,445 & 324 & 256 \\
25D & $40 \times 40$ & $2.00 \times 2.00$ & 2,500 & 400 & 256 \\
11D & $40 \times 40$ & $3.00 \times 3.00$ & 1,110 & 156 & 90 \\
6D & $40 \times 40$ & $4.00 \times 4.00$ & 625 & 100 & 64 \\
2D & $40 \times 40$ & $6.00 \times 6.00$ & 278 & 49 & 25 \\
1D & $60 \times 60$ & $8.00 \times 8.00$ & 157 & 64 & 36 \\
\hline
\end{tabular}

Experiment on 44D, 2D and 1D was not carried out for M. azedarach and on 11D for $A$. indica.

from 1984 to 1989. A few trees were sampled from each plot for dry weight measurement at the same time. The total above-ground dry weight of each tree in each plot was estimated by allometric relations obtained by sample trees (Appendices $1 \mathrm{a}$ and $1 \mathrm{~b}$ ). The mean total aboveground dry weight (mean tree weight) of each plot was calculated for each year. The procedures for data handling were the same as those adopted for E. camaldulensis plantations which were shown in the preceding paper (Thoranisorn et al., 1990).

\section{Mean tree weight-density relation and mean tree weight-density trajectory}

The relationship between mean tree weight and tree density ( $w$ - $\rho$ relation) at a given time was approximated by the reciprocal equation of density effect (C-D effect), derived from the logistic growth equation (Shinozaki \& Kira 1956),

$$
\begin{aligned}
\frac{1}{w} & =A \rho+B \\
& =A \rho+\frac{e^{-\tau}}{w_{0}}
\end{aligned}
$$

where $w$ is mean tree weight, $\rho$ is actual density, and $A$ and $B$ are coefficients of the reciprocal equation at a given time. The variable $\tau$ is the biological time. The variable $w_{0}$ is initial tree weight which is independent of stand density. Their notations and units are given in Table 2 together with those of the other coefficients.

Mean tree weight-density trajectories ( $w-\rho$ trajectory) were used for describing the correlated changes of mean tree weight with tree density during a self-thinning process in evenaged monospecific populations that started from different initial tree density and grew in the same environmental conditions. These trajectories have been described by Hozumi's model (1977) and are written in the form,

$$
\left.\begin{array}{c}
\frac{1}{w}=\frac{p \rho}{w_{\mathrm{O}}} \mathrm{Q}^{1-\beta}\left[1-\mathrm{Q}^{\beta-1 / \alpha}\right]+\frac{1}{w_{\mathrm{O}}} \mathrm{Q}^{-1 / \alpha} \\
\mathrm{Q}=1+\frac{1}{p}\left(\frac{1}{\rho}-\frac{1}{\rho_{\mathrm{i}}}\right)
\end{array}\right]
$$

$p$ is an empirical constant, coefficients $\alpha$ and $\beta$ are positive constants determined for the pop- 
Table 2. Nomenclature of variables, their explanation and units.

\begin{tabular}{lll}
\hline Symbols & \multicolumn{1}{c}{ Explanations } & Units \\
\hline$A$ & $\begin{array}{l}\text { Cofficient of reciprocal equation of } \\
\text { competition-density effect }\end{array}$ & $\mathrm{ha} \mathrm{kg}^{-1}$ \\
$B$ & $\begin{array}{l}\text { Cofficient of reciprocal equation of } \\
\text { competition-density effect }\end{array}$ & \\
& Mean tree weight & $\mathrm{kg}^{-1}$ \\
$w$ & Initial mean tree weight & $\mathrm{kg}$ \\
$w_{\mathrm{o}}$ & Realzied density & $\mathrm{kg}$ \\
$\rho$ & Initial density & $\mathrm{ha}^{-1}$ \\
$\rho_{\mathrm{i}}$ & Empirical constant & $\mathrm{ha}^{-1}$ \\
$p$ & Empirical constant & $\mathrm{ha}$ \\
$\alpha$ & Empirical constant & dimensionless \\
$\beta$ & Empirical constant & dimensionless \\
$g$ & Empirical constant & year \\
$h$ & Intrinsic growth rate of the logistic & dimensionless \\
$\lambda$ & growth curve & \\
& Lag time & year-1 \\
$L$ & Biological time & year \\
$\tau$ & Years after planting & dimensionless \\
$t$ & & year \\
\hline
\end{tabular}

ulation concerned, and the variable $\rho_{\mathrm{i}}$ is the initial stand density. It is difficult to determine the suitable values of the coefficients in Eq. 2 directly from the equation. Coefficients $p, \alpha, \beta$ could be determined from $A(\tau)-\tau$ relation when $A(\tau)$ and $\tau$ were determined from the experimental data. $A(\tau)-\tau$ relation is in the form,

$$
A(\tau)=\frac{p}{w_{0}} e^{\alpha(1-\beta) \tau}\left\{1-e^{(\alpha \beta-1) \tau}\right\}
$$

All coefficients of the model were determined by the non-linear least square method (Grass, 1967). The data manipulations in this study were the same as those in the previous study (Thoranisorn et al., 1990).

\section{RESULTS}

\section{Density effect on mean DBH and mean $\mathrm{H}$}

Table 3 shows mean stem diameter at breast height $(D B H)$ and mean tree height $(H)$ of $M$. azedarach and $A$. indica after six years from transplanting in various tree densities. Both mean $D B H$ and mean $H$ were clearly decreased with corresponding increase of tree density. For a stand of given density, $M$. azedarach at S-site had larger mean $D B H$ and mean $H$ than that of $A$. indica at R-site. But they were smaller than those of $E$. camaldulensis of the comparable age and tree density at S-site found in the former study (Thoranisorn et al., 1990). Mean $D B H$ obtained from $M$. azedarach stand of the lowest density was 4.3 times larger and mean $H$ was 1.9 times higher than that from the highest density one. The differences in mean $D B H$ and mean $H$ between the lowest and highest densities were 8.6 times and 3.1 times respectively in $A$. indica stands. As the result, $D B H$ seemed to be respond more sensitively to tree density than $H$ in the period of the study. 
Table 3. Mean $D B H \pm \mathrm{SD}$, mean $H \pm \mathrm{SD}$ and survival rate of six year-old $M$. azedarach and $A$. indica plantations.

\begin{tabular}{|c|c|c|c|c|c|c|}
\hline \multirow{2}{*}{$\begin{array}{l}\text { Initial } \\
\text { density } \\
\text { (trees ha-1) }\end{array}$} & \multicolumn{3}{|c|}{ M. azedarach } & \multicolumn{3}{|c|}{ A. indica } \\
\hline & $\begin{array}{l}D B H \\
(\mathrm{~cm})\end{array}$ & $\begin{array}{c}H \\
\text { (m) }\end{array}$ & $\begin{array}{l}\text { Survival rate } \\
(\%)\end{array}$ & $\begin{array}{r}D B H \\
(\mathrm{~cm})\end{array}$ & $\begin{array}{l}H \\
\text { (m) }\end{array}$ & $\begin{array}{c}\text { Survival rate } \\
(\%)\end{array}$ \\
\hline 40,000 & $3.9 \pm 2.2$ & $7.4 \pm 2.9$ & 45.6 & $1.9 \pm 0.9$ & $2.9 \pm 1.3$ & 91.8 \\
\hline 17,778 & $5.2 \pm 2.3$ & $8.7 \pm 2.9$ & 74.3 & $3.1 \pm 1.3$ & $4.4 \pm 1.5$ & 95.2 \\
\hline 10,000 & $5.5 \pm 2.3$ & $7.1 \pm 2.3$ & 84.7 & $4.8 \pm 1.9$ & $5.9 \pm 2.0$ & 97.5 \\
\hline 4,445 & - & 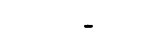 & - & $6.4 \pm 2.2$ & $6.9 \pm 2.2$ & 98.4 \\
\hline 2,500 & $9.3 \pm 3.2$ & $9.8 \pm 2.9$ & 81.2 & $6.7 \pm 2.2$ & $6.1 \pm 1.6$ & 98.4 \\
\hline 1,110 & $13.1 \pm 3.2$ & $14.1 \pm 2.1$ & 91.1 & - & - & - \\
\hline 625 & $16.9 \pm 3.6$ & $14.1 \pm 2.0$ & 89.1 & $13.0 \pm 2.4$ & $9.8 \pm 1.3$ & 98.4 \\
\hline 278 & - & - & - & $14.8 \pm 2.7$ & $9.4 \pm 1.0$ & 92.1 \\
\hline 157 & - & - & - & $16.5 \pm 5.1$ & $9.1 \pm 2.0$ & 100.0 \\
\hline
\end{tabular}

\section{Mortality of trees}

Changes of tree density with time in each plot of $M$. azedarach and A. indica are shown in Fig.1. Higher mortality of trees in denser stand were found in $M$. azedarach plots. In six years after the planting, 55\% of initial planted trees died in the plot with highest tree density (400D) of M. azedarach at S-site. Dead trees were mostly small-sized individuals. The higher mortality of smaller trees in denser stand was believed to be due to a crowding effect. For $A$. indica at R-site, the mortality was far lower than that for $M$. azedarach stands, and more than $90 \%$ of planted trees in all plots survived in the study period of six years (Table 3 ).

\section{Effect of tree density on mean tree weight and $w-\rho$ trajectory}

Trees planted in higher density were smaller in size. In six year-old stand, mean tree weight

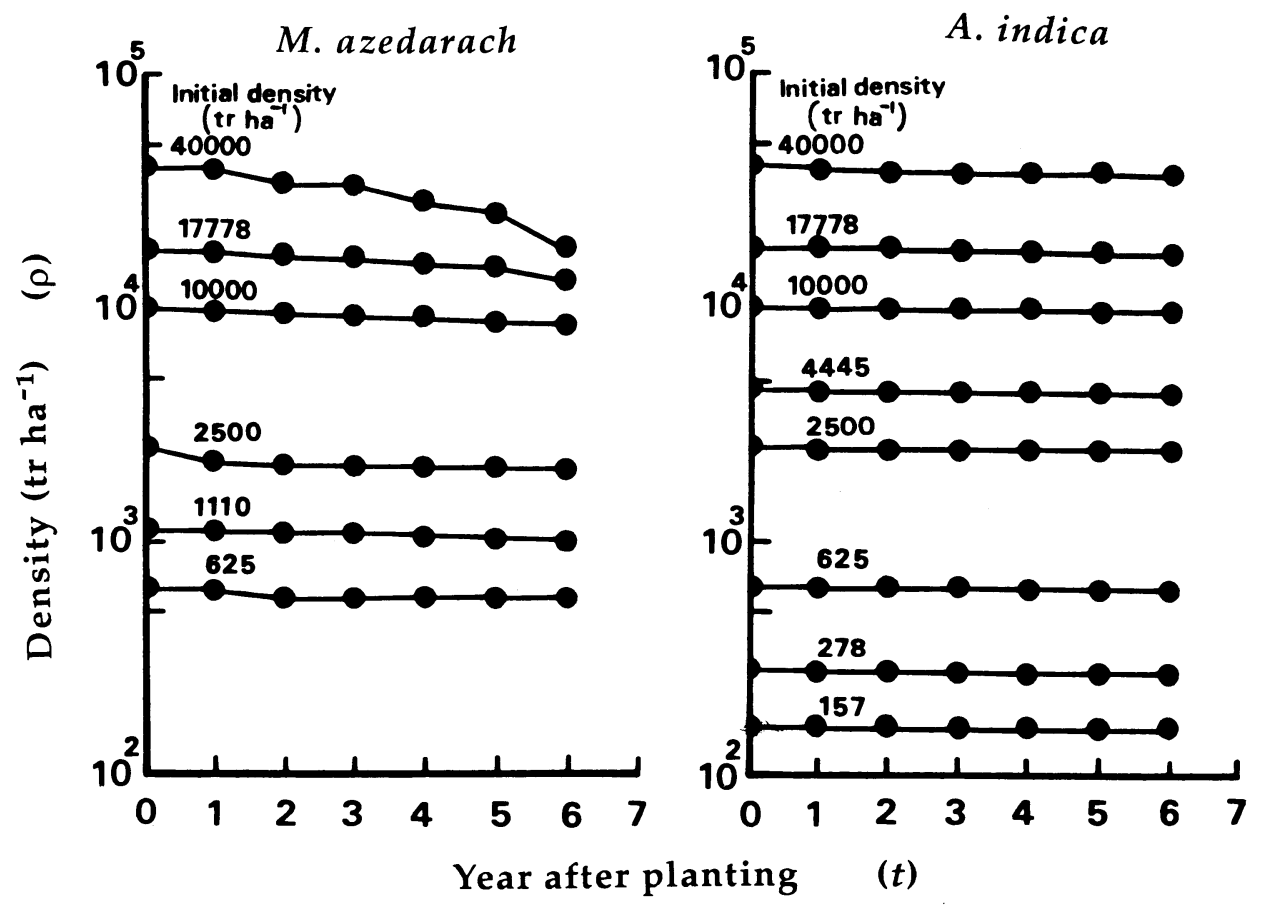

Fig. 1. Changes of tree density with time in M. azedarach and A. indica plantations. 
in stands of various tree densities ranged from $3.98-89.81 \mathrm{~kg}$ and $0.84-59.70 \mathrm{~kg}$ for $M$. azedarach and $A$. indica, respectively. The relationship between mean tree weight and tree density was approximated by the C-D effect model in Eq. 1 (Fig. 2). Values of coefficients $A$ and $B$ are shown in Table 4. The values of $A$ and $B$ decreased gradually with the increase of time from one year-old to six year-old. From the result, $B$ values for $M$. azedarach were always smaller than those for $A$. indica in the corresponding years, suggesting that weight of $M$. azedarach was larger than $A$. indica in the stand without competition $(\rho \rightarrow 0)$ at any time of growth. In this study, initial tree weight $w_{0}$ was $0.002 \mathrm{~kg}$ tree $\mathrm{e}^{-1}$ and $0.0006 \mathrm{~kg}$ tree ${ }^{-1}$ for $M$. azedarach and $A$. indica, respectively. The value of each species was used for calculating $\tau$ values in Eq. 1 (Table 4).

Coefficient $A$ in Eq. 1 is a function of $\tau$ as shown in Eq. 3. The fitness of the model of Eq. 3 to the observed values of $M$. azedarach and A. indica (Table 4) was practically satisfied (Fig. 3). Values of coefficients $p, \alpha$ and $\beta$ are shown in Table 5. At the initial stage of growth, mean tree weight was independent of stand density. It was equal to $w_{0}$ hence $\tau=0, A=0$. After a rapid increase of $A$ with an increase of $\tau$ in the early stage after planting (Fig. 3), $A$ attained its maximum value $\left(1.1942 \times 10^{-4}\right.$ for $M$. azedarach and $2.2769 \times 10^{-4}$ for $A$. indica) at the specific value of $\tau$ (2.1751 for $M$. azedarach and 2.0090 for $A$. indica). Then $A$ decreased exponentially with $\tau$ afterwards. The $A(\tau)-\tau$ diagram (Fig. 3) for $M$. azedarach and $A$. indica determined by Eq. 3 showed that the growth pattern of the two species followed the $\lambda \mathrm{N}$ type
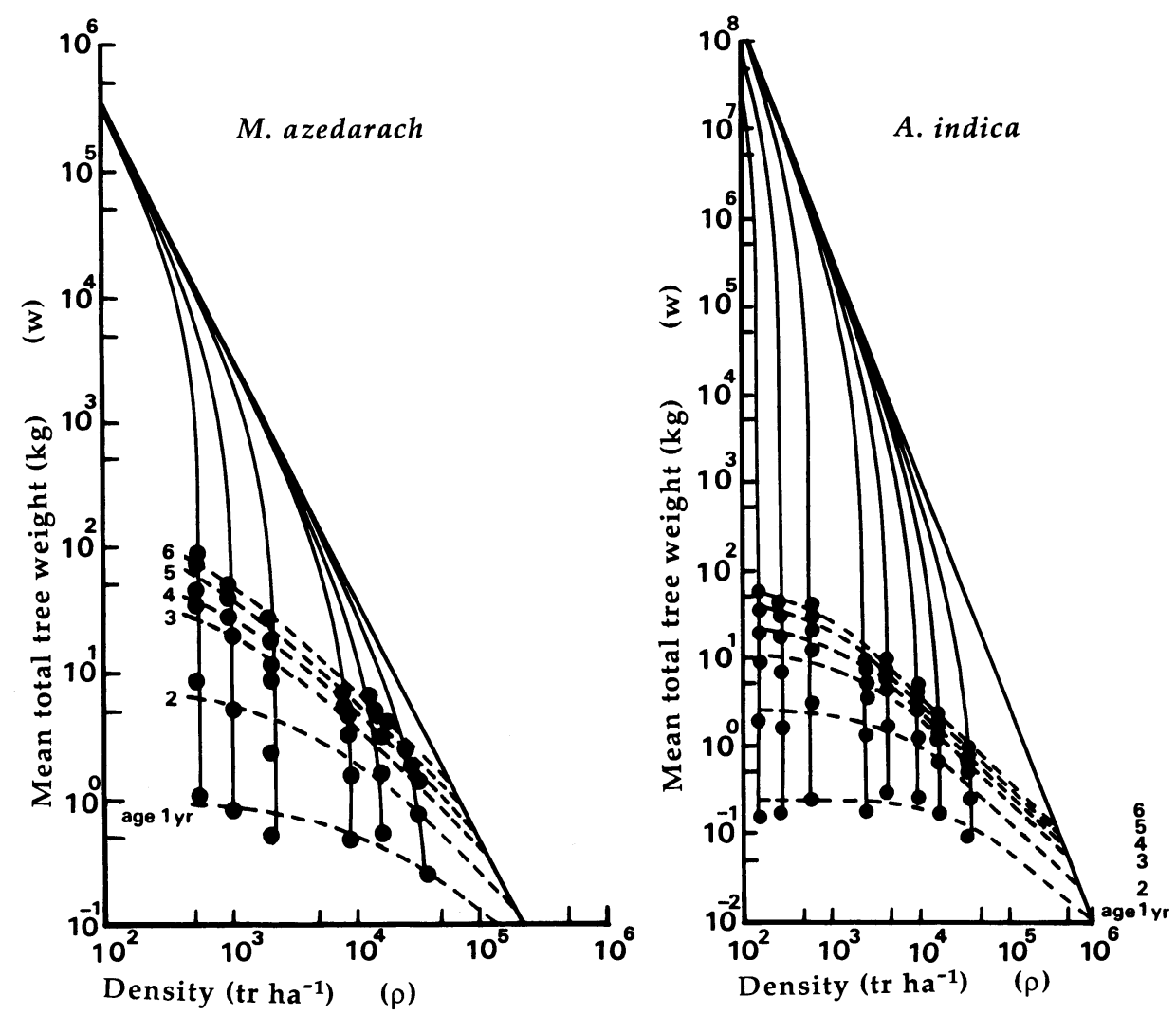

Fig. 2. $w$ - $\rho$ relation (Eq. 1) at a specific $\tau$ or at a given time (dash lines) and $w$ - $\rho$ trajectory (Eq.2) corresponding to different levels of initial density (solid lines) of M. azedarach and $A$. indica plantations on log-log coordinates. 
Table 4a. Constant values of $w-\rho$ relationship $(1 / w=A \rho+B)$, biological time $(\tau)$ and intrinsic growth rate $(\lambda=\Delta \tau / \Delta t)$ of the time-specific logistic growth curve of the mean total tree weight of $M$. azedarach plantations.

\begin{tabular}{|c|c|c|c|c|}
\hline $\begin{array}{l}\text { Years after } \\
\text { planting } \\
\text { (years) }\end{array}$ & $\begin{array}{c}A \\
\left(\mathrm{ha} \mathrm{kg}^{-1}\right)\end{array}$ & $\begin{array}{c}B \\
\left(\mathrm{~kg}^{-1}\right)\end{array}$ & $\bar{\tau}$ & $\begin{array}{c}\lambda \\
\left(\mathrm{yr}^{-1}\right)\end{array}$ \\
\hline 1 & $6.6596 \times 10^{-5}$ & $107.9460 \times 10^{-2}$ & 6.1382 & 6.1382 \\
\hline 2 & $3.6476 \times 10^{-5}$ & $12.5511 \times 10^{-2}$ & 8.2899 & 2.1517 \\
\hline 3 & $2.3041 \times 10^{-5}$ & $1.9875 \times 10^{-2}$ & 10.1329 & 1.8430 \\
\hline 4 & $1.9256 \times 10^{-5}$ & $1.3997 \times 10^{-2}$ & 10.4835 & 0.3506 \\
\hline 5 & $1.6257 \times 10^{-5}$ & $0.6259 \times 10^{-2}$ & 11.2883 & 0.8048 \\
\hline 6 & $1.3467 \times 10^{-5}$ & $0.4606 \times 10^{-2}$ & 11.5951 & 0.3068 \\
\hline
\end{tabular}

Table 4b. Constant values of $w$ - $\rho$ relationship $(1 / w=A \rho+B)$, biological time $(\tau)$ and intrinsic growth rate $(\lambda=\Delta \tau / \Delta t)$ of the time-specific logistic growth curve of the mean total tree weight of $A$. indica plantations.

\begin{tabular}{lcrrr}
\hline $\begin{array}{c}\text { Years after } \\
\text { planting } \\
\text { (years) }\end{array}$ & $A$ & $B$ & $\tau$ & $\lambda$ \\
\hline 1 & $10.2046 \times 10^{-5}$ & $383.3100 \times 10^{-2}$ & 6.0749 & \multicolumn{1}{c}{$\left(\mathrm{ha} \mathrm{kg}^{-1}\right)$} \\
2 & $6.3269 \times 10^{-5}$ & $37.2674 \times 10^{-2}$ & 8.4056 & 6.0749 \\
3 & $3.8254 \times 10^{-5}$ & $8.4755 \times 10^{-2}$ & 9.8866 & 1.4307 \\
4 & $3.3742 \times 10^{-5}$ & $3.9128 \times 10^{-2}$ & 10.6595 & 0.7729 \\
5 & $2.7399 \times 10^{-5}$ & $2.1360 \times 10^{-2}$ & 11.2648 & 0.6053 \\
6 & $2.3102 \times 10^{-5}$ & $1.3155 \times 10^{-2}$ & 11.7496 & 0.4848 \\
\hline
\end{tabular}

of logistic growth (Shinozaki \& Kira, 1956).

Changes in mean tree weight and tree density at each initial planting density were described by the Hozumi's model shown in Eq. 2. The coefficients of the model were determined by Eq. 3 (Table 5). The fitness of the model to the observed data for M. azedarach and $A$. indica is shown in Fig. 2. However, $\beta$ values showing the slope of self-thinning line in Fig. 2 differed from $3 / 2$ for both species, and had a steeper slope than prediction from the $3 / 2$ power law of self-thinning (Yoda et al., 1963 ; Hozumi, 1977, 1980).

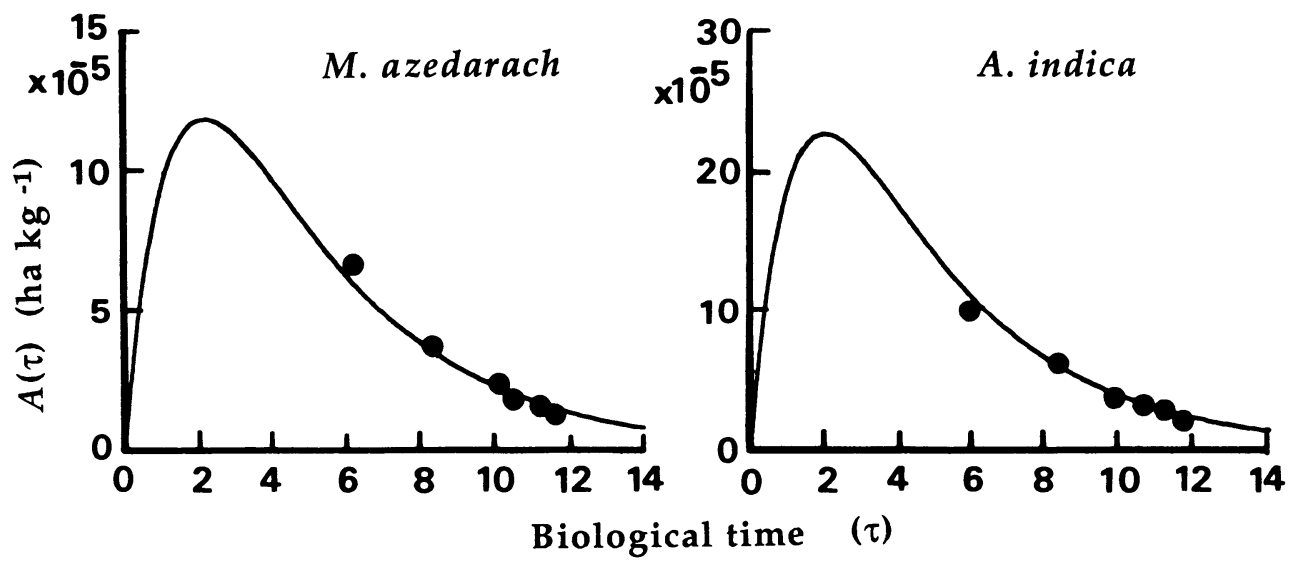

Fig. 3. $A(\tau)$ - $\tau$ relation (Eq. 3) for M. azedarach and $A$. indica plantations. 
Table 5. Values of coefficients in the Hozumi's model of $A(\tau)-\tau$ relation for some forest plantations.

\begin{tabular}{|c|c|c|c|c|}
\hline Species & $\alpha$ & $\beta$ & $p$ & MRE \\
\hline \multirow[t]{2}{*}{ M. azedarach } & 0.2734 & 1.98 & $6.7764 \times 10^{-7}$ & 0.0604 \\
\hline & 0.2543 & 1.50 & $2.5988 \times 10^{-7}$ & $0.3868^{a}$ \\
\hline \multirow[t]{2}{*}{ A. indica } & 0.1733 & 2.56 & $3.4945 \times 10^{-7}$ & 0.0473 \\
\hline & 0.2776 & 1.50 & $1.0126 \times 10^{-7}$ & $0.2615^{a}$ \\
\hline E. camaldulensis $\mathrm{b}$ & 0.4529 & 1.50 & $5.4293 \times 10^{-7}$ & 0.1041 \\
\hline P. strobus $\mathrm{c}$ & 0.3800 & 1.50 & $7.5460 \times 10^{-7}$ & - \\
\hline
\end{tabular}

MRE is mean relative error.

a : Coefficients values were caculated by fitting $\beta=1.50$.

b : Coefficients values reported by Thoranisorn et al. (1990).

c : Coefficients values reported by Hozumi (1977).

\section{Growth analysis based on the logistic theory}

According to the logistic theory of plant growth (Shinozaki \& Kira 1956), $\lambda$ is a mean intrinsic growth rate which independent of tree density. $\lambda$ value could be estimated from the result of the experiment as $\lambda(t)=\mathrm{d} \tau / \mathrm{d} t=\Delta \tau / \Delta t$ (Shinozaki \& Kira 1956). This value changed with time $(t)$ for $M$. azedarach and A. indica in the study. Biological time $(\tau)$ could be used as a parameter for indicating the growing stage of plant. The relation between $\tau$ and $t$ could be approximated by the hyperbolic curve which fitted well to that for P. strobus (Hozumi, 1977) and E. camaldulensis (Thoranisorn et al., 1990). The relationship is

$$
\frac{1}{\tau}=\frac{g}{t-L}+h
$$

where $g$ and $h$ are constants specific to the experiment, and $L$ is a lag time which was considered to be the time at the initial stage after planting that seedlings used for adapting to the new site condition, recovering from planting injury, etc., and they started to grow after the lag time (Hozumi, 1977 ; Thoranisorn et al., 1990). The $\lambda-t$ relation could be obtained by differentiating both sides of Eq. 4 with respect to $t$ and has the form,

$$
\lambda(t)=\frac{g}{\{g+h(t-L)\}^{2}}
$$

The $\tau-t$ relation and $\lambda-t$ relation are shown in Fig. 4 and Fig. 5, respectively. The approximated coefficient values were $g=9.3666 \times 10^{-2}, h=7.0436 \times 10^{-2}$ for $M$. azedarach and $g=9.6012 \times 10^{-2}, h=6.9545 \times 10^{-2}$ for $A$. indica and $L=0$ for both species in the study. It was found that the lag time for tropical plantations was very short when compared with that for $P$. strobus ( $L=2.5$ years) plantation in temperate region (Hozumi, 1977). Moreover, the ceiling value of $\tau$ as $t$ tended to infinity for three tropical trees were almost identical; $\tau=14.20$, 14.38 and 13.37 for $M$. azedarach, $A$. indica and E. camaldulensis, respectively.

\section{DISCUSSION}

The knowledge of density effect in plant populations should contribute to the efficient management of tropical tree plantations. It was obvious that tree density affected tree size, tree 


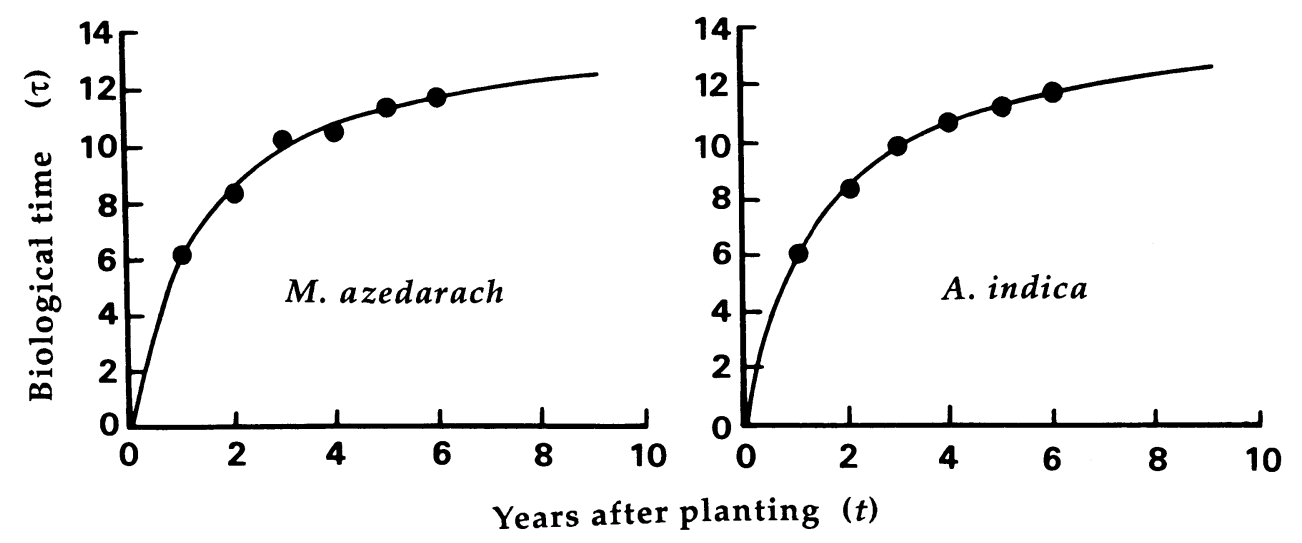

Fig. 4. The $\tau-t$ relation in $M$. azedarach and $A$. indica plantations. Dots are the same as in Table 4, the lines are drawn according to Eq. 4.

growth and development of forest stands. Smaller trees often died when the trees grown at a closer spacing or in high tree density by the competition between individuals (Harper, 1977). The evidence was observed in M. azedarach plantations (Fig. 1) at S-site but was not remarkable for $A$. indica plantations at R-site during the study period. Various factors determine the mortality of trees during the self-thinning process. In general, the high mortality is associating with fertile soil condition, faster tree growth and higher tree density. Consequently, the selfthinning process will proceed quicker than that on poor soil.(Clark, 1990 ; Harper, 1977 ; White \& Harper, 1970). Yoda et al. (1963) reported that less fertile soil supported a larger number of small trees under overcrowded condition. In this study, less mortality of trees in $A$. indica plantations was due to their slow growth on very poor soil condition at $\mathrm{R}$-site. Soils of this site characterized by high percentage of heavy clay, rock fragment and gravel, which will prevent root growth and water permeability (Sakurai et al., 1989). The productivity of this site was a half of that at $\mathrm{S}$-site in E. camaldulensis plantations (Kanzaki et al., unpubl.).

Regarding parameters of the Hozumi's model in Table 5, $\beta$ value for $M$. azedarach (1.98) and $A$. indica (2.56) differed from 3/2, although Hozumi (1977) suggested that $\beta$ value was

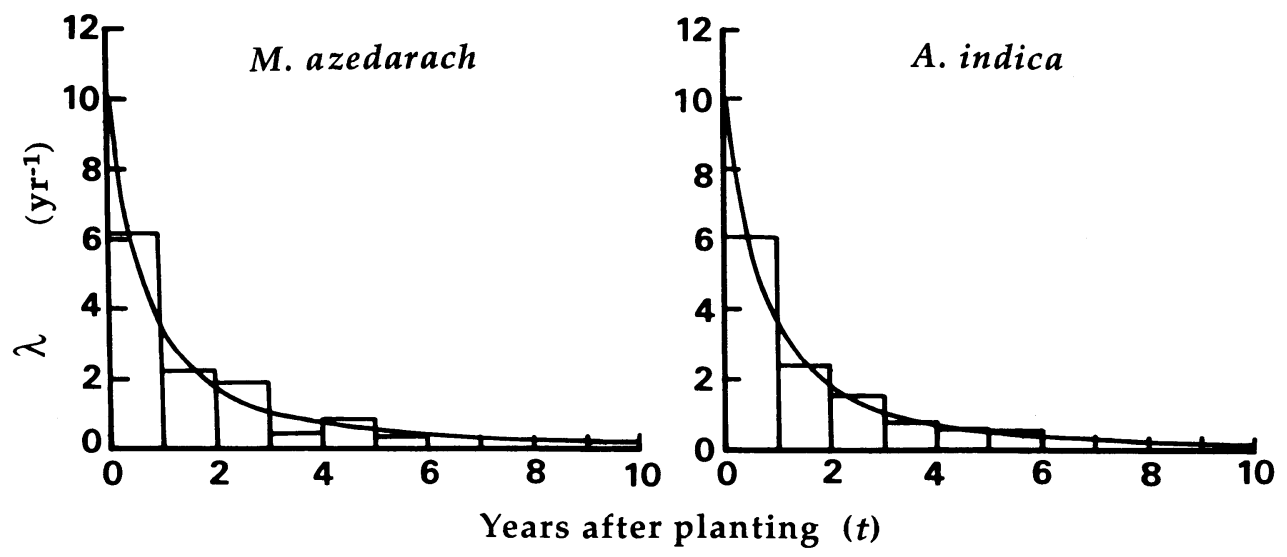

Fig. 5. Changes of $I$ with time of $M$. azedarach and $A$. indica plantations.

Bars denote the estimated $\lambda$ as $\Delta \tau / \Delta t$ in each period (shown in Table 4). The line shows the relationship calculated by Eq. 5 . 
expected to vary within a limited range around $3 / 2$. This is due to the lack of tree death in all plots during six years of this study. The $\beta$ value for $M$. azedarach having higher mortality rate was closer $3 / 2$ than that for A. indica. We determined the coefficients in Eq. $2, \alpha$ and $p$, by fixing the $\beta$ as $3 / 2$ by non-linear least square method, but the fitness of the calculated values to the observed data was not so good for both species. Mean relative error was large as shown in Table 5. The $\alpha$ value for $A$. indica which had the lowest mortality rate was the lowest. The $p$ value for $M$. azedarach was highest and followed by $E$. camaldulensis and A. indica. But values of $p$ for the three tropical trees were lower than that for P. strobus (Hozumi, 1977).

The tropical tree plantations in this study had higher biomass growth rate as compared with that for temperate tree plantations. Total above-ground biomass in six year-old $E$. camaldulensis, $M$. azedarach and $A$. indica plantations ranged from 54-110 tha ${ }^{-1}, 49-87 \mathrm{tha}^{-1}$ and 9-50 $\mathrm{t} \mathrm{ha}^{-1}$, respectively, while the total above-ground biomass of 10 year-old Cryptomeria japonica plantations in Japan ranged from 31-69 $\mathrm{t} \mathrm{ha}^{-1}$ (Ando et al., 1968 ; Kawanabe et al., 1975). For management of tropical tree plantations, $\tau$ value could be used as a parameter for indicating the growing stage of tree. $\tau$ values for six year-old $M$. azedarach and $A$. indica, and that for the same aged $E$. camaldulensis plantations in the previous study were about 80 $86 \%$ of their maximum values. It is indicating that these six year-old plantations will already be in the late growing stage having relatively low growth potential. The Hozumi's model was effectively applicable to the growth and developing patterns of pure stands of both tropical pioneer trees as well as those of temperate trees. We are able to estimate the biomass, mean tree size at any given time from the planting and initial or actual tree density, and their growth in future using the obtained tree growth and stand development patterns of both species. If we have information about costs for the plantation management, size depending price of timber, price of wood for fuel or that of chips for paper mill, etc., we could suggest the most commercially efficient planting density or spacing and the time of harvesting according to the purpose of utilization of the plantation. However, further intensive researches in these tropical forest plantations must be done in longer period and extend to other tropical tree species for well understanding the growth characteristics and stand development of the species. These knowledge are very important for efficient management of the forest plantations.

ACKNOWLEDGMENTS The authors are indebted to Dr. T. Yamakura, Dr. M. Kanzaki of Osaka City University and Dr. P. Dhanmanonda of Kasetsart University for their valuable suggestions and guidance. We are highly grateful to Dr. H. Kawaguchi of Kyoto University for his computer programming for data analysis in this study. Thanks are also extend to the Royal Forest Department and the Forest Industry Organization of Thailand for permitting us to work in the area.

\section{REFERENCES}

Ando, T. 1968. Ecological studies on the stand density control in even-aged pure stand. Bulletin of The Government Forest Experiment Station, Tokyo, 210: 1-153. (in Japanese)

Ando, T., Hatiya, K., Doi, K., Kataoka, H., Kato, Y. \& Sakaguchi, K. 1968. Studies on the system of density control of sugi (Cryptomeria japonica) stand. Bulletin of The Government Forest Experiment Station. Tokyo, 209: 1-76. (in Japanese)

Brown, S., Lugo, A. E. \& Chapman, J. 1986. Biomass of tropical tree plantations and its 
implications for the global carbon budget. Canadian Journal of Forest Research 16: 390394.

Clark, J. S. 1990. Integration of ecological levels : Individual plant growth, population mortality and ecosystem processes. Journal of Ecology 78: 275-299.

Drew, T. J. \& Flewelling, J. W. 1977. Some recent Japanese theories of yield-density relationships and their application to monterey pine plantations. Forest Science 23: 517-534.

Evans, J. 1983. Plantation Forestry in the Tropics. ELBS Oxford. 472 pp.

Glass, N. R. 1967. A technique for fitting nonlinear models to biological data. Ecology 48: 1010-1013.

Harms, W. R. \& Langdon, O. G. 1976. Development of loblolly pine in dense stands. Forest Science 22: 331-337.

Harper, J. L. 1977. Population Biology of Plants. Academic Press, London. 892 pp.

Hozumi, K. 1977. Ecological and mathematical considerations on self-thinning in even-aged pure stands. I. Mean plant weight-density trajectory during the course of self-thinning. Botanical Magazine Tokyo 90: 165-179.

Hozumi, K. 1980. Ecological and mathematical considerations on self-thinning in even-aged pure stands. II. Growth analysis of self-thinning. Botanical Magazine Tokyo 93: 149-166.

Kawanabe, S., Saito, H. \& Shidei, T. 1975. Studies on the effects of thinning small diametered trees. V. Changes in stand conditions and biomass of Cryptomeria japonica D. Don. stand during six years after thinning. Journal of The Japanese Forestry Society 57: 215223. (in Japanese)

Kongsangchai, J. 1988. Forest ecological study of mangrove silviculture. Doctor Thesis, Kyoto University, $112 \mathrm{pp}$.

Lanly, J. P. 1982. Tropical forest resources. FAO Forestry Papers, 30, 106 pp.

Lugo, A., Brown, S. \& Chapman, J. 1988. An analytical review of production rates and stemwood biomass of tropical forest plantations. Forest Ecology and Management 23: 179-200.

Sakurai, K., Araki, S., Naganawa, T., Iwatsubo, G., Attanandana, T. \& Prachaiyo, B. 1989. Improvement of biological productivity in degraded lands in Thailand. I. Site and profile descriptions of the experimental sites. Pedologist 33: 17-29.

Shinozaki, K. \& Kira, T. 1956. Intraspecific competition among higher plants. VII. Logistic theory of the C-D effect. Journal of The Institute of Polytechnics, Osaka City University D7: 35-72.

Thoranisorn, S., Sahunalu, P. \& Yoda, K. 1990. Density effects and self-thinning in even-aged pure stands of Eucalyptus camaldulensis Dehn. Botanical Magazine Tokyo 103: 283-295.

Wadsworth, F. H. 1983. Production of usable wood from tropical forest. In Golley F. B. (ed.), Tropical Rain Forest Ecosystems : Structure and Function, 279-288. Elsevier, Amsterdam.

White, J. \& Harper, J. L. 1970. Correlated changes in plant size and number in plant populations. Journal of Ecology 58: 467-485.

Whitmore, T. C. 1990. An Introduction to Tropical Rain Forest. Clarendon Press, Oxford. 226 pp.

Yoda, K., Kira, T., Ogawa, H. \& Hozumi, K. 1963. Self-thinning in overcrowded pure stands under cultivated and natural condition. (Intraspecific competition among higher plants XI). Journal of Biology, Osaka City University 14: 107-129. 
Appendix 1a. Regression constants of allometric equations $\left(y=a x^{b}\right)$

for estimating biomass of $M$. azedarach for all planting densities.

\begin{tabular}{lcccc}
\hline $\begin{array}{l}\text { Plant } \\
\text { part }\end{array}$ & $\begin{array}{c}\text { Age } \\
\text { a } \\
\text { (years) }\end{array}$ & & b & \\
& & & $\mathrm{r}^{2}$ & \\
\hline Stem & $1^{*}$ & 0.0116 & 0.9326 & 0.96 \\
& 2 & 0.0849 & 2.2277 & 0.96 \\
& 3 & 0.0854 & 2.2854 & 0.98 \\
& 4 & 0.1126 & 2.0998 & 0.98 \\
& 5 & 0.0972 & 2.2589 & 0.98 \\
\hline Branch & $1^{*}$ & 0.0003 & 1.3784 & 0.71 \\
& 2 & 0.0014 & 3.0639 & 0.70 \\
& 3 & 0.0020 & 3.3464 & 0.90 \\
& 4 & 0.0057 & 2.8094 & 0.86 \\
& 5 & 0.0051 & 2.9302 & 0.88 \\
\hline Leaf & $1^{*}$ & 0.0064 & 0.9662 & 0.86 \\
& 2 & 0.0095 & 1.9448 & 0.68 \\
& 3 & 0.0021 & 2.4809 & 0.78 \\
& 4 & 0.0178 & 2.0191 & 0.91 \\
& 5 & 0.0059 & 2.4404 & 0.92 \\
\hline
\end{tabular}

Total tree dry weight $=$ Stem + Branchs + Leaves

$\mathrm{x}=D B H(\mathrm{~cm}), \mathrm{y}=$ biomass of each plant part $(\mathrm{kg})$, while 1 year- old stand with asterisk $\left(^{*}\right), \mathrm{x}=D_{\mathrm{o}}^{2} H\left(\mathrm{~cm}^{2} \mathrm{~m}, D_{\mathrm{o}}\right.$ is stem diameter at ground level).

Appendix 1b. Regression constants of allometric equations $\left(y=a x^{b}\right)$

for estimating biomass of $A$. indica for all planting densities.

\begin{tabular}{lcccc}
\hline $\begin{array}{l}\text { Plant } \\
\text { part }\end{array}$ & $\begin{array}{c}\text { Age } \\
\text { (years) }\end{array}$ & $\mathrm{a}$ & $\mathrm{b}$ & $\mathrm{r}^{2}$ \\
\hline Stem & 1 & 0.0097 & 0.9615 & 0.96 \\
& 2 & 0.0085 & 1.0043 & 0.98 \\
& 3 & 0.0118 & 0.9637 & 0.99 \\
& 4 & 0.0127 & 0.9492 & 0.98 \\
& 5 & 0.0147 & 0.9382 & 0.99 \\
\hline Branch & 1 & 0.0019 & 0.9764 & 0.70 \\
& 2 & 0.0006 & 1.0815 & 0.74 \\
& 3 & 0.0008 & 1.0625 & 0.86 \\
& 4 & 0.0002 & 1.2874 & 0.81 \\
& 5 & 0.0011 & 1.0547 & 0.88 \\
\hline Leaf & 1 & 0.0229 & 0.7096 & 0.88 \\
& 2 & 0.0126 & 0.7364 & 0.83 \\
& 3 & 0.0076 & 0.8203 & 0.95 \\
& 4 & 0.0016 & 0.9941 & 0.89 \\
& 5 & 0.0021 & 0.9654 & 0.96 \\
\hline
\end{tabular}

Total tree dry weight $=$ Stem + Branchs + Leaves

$\mathrm{x}=D_{\mathrm{o}}{ }^{2} H\left(\mathrm{~cm}^{2} \mathrm{~m}, D_{\mathrm{o}}\right.$ is stem diameter at ground level),

$\mathrm{y}=$ biomass of each plant part $(\mathrm{kg})$

\section{S. THORANISORN, P. SAHUNALU，依田恭二 熱帯造林地における密度効果と生長解析}

熱帯地域に扔ける人工造林の是非は状況と目的に依存するものの，1）荒廃した森林を修復 し、森林の絶対面積を拡大する働き，2) 地球規模の炭素循環で二酸化炭素のシンクとなる働 き，3）薪炭材・チップ材 · 用材などの木材資源の他、家畜飼料や樹脂等の多様な林産物を供 給して結果的に自然林を開発の手から守る可能性など, その効用には無視しえないものが多 
い.しかしながら，熱帯造林には生長要因が林木に及ほす効果を始め，技術的にも生物学的に も解明されていない点が多い。人工林の管理は通常単位面積あたりの林木個体数である密度を 基本にして行われる，林木の生長に必要な水や無機養分などとは異なり，密度は特異な性質を 持った生長要因であり, 密度が増えれば増えるほど個体の生長は抑制されるが, 林分全体の収 量 (現存量) は逆に増加する. 本研究は, 熱帯造林でしばしば用いられるタイワンセンダン (Melia azedarach)とインドセンダン (Azadirachta indica) 2種の実験モデル林分で 6 年間にわたって 生長を追跡し, 密度が林木と林分発達に及ほす効果を調べたものである. 研究はタイで行わ れ，実験に用いた 2 種はタイにも自生する。

1.タイワンセンダンの実験地は東北タイのソムデット (Somdet), インドセンダンの実験地 は西夕イのラチャブリ (Ratchaburi) で, この2地区には夕イ林産公社と林野局の造林試験地があ る. ソムデットの土壤は砂質ローム, ラチャブリの土壤はラテライト性土であり, 土塞の肥沃 度はソムデットの方が高いと思われた. 密度のレベルはタイワンセンダンに対して6段階 (625 〜 40,000/ha), インドセンダンに対して8段階 (187〜40,000/ha) とした。

2. 最大密度区 $(40,000 / \mathrm{ha})$ における6年間の死亡率は, タイワンセンダンで $54 \%$, インドセ ンダンで $8 \%$ であり，土壌の肥沃度の低い条件下で栽培されたインドセンダンの生長が抑制さ れ，こみあい効果による個体の死亡が起きにくかったことを示している.

3. 高密度区では低密度区に比べ個体の生長が抑制された。この現象は良く知られており， 従来の一般的知見と矛盾しない. 個体の生長を平均個体重で表し, 密度と平均個体重の関係を 調べると，その関係は穂積が提案した密度〜平均個体重の数学モデル（穂積モデル）に良く適 合した．データをモデルに当てはめ，モデルの係数を非線形最小自乗法によって推定し，2種 間で係数を比較した。係数の諸性質を調べると，2種の生長が篠崎の提唱する一般化ロジスチ ック曲線に従うことが示唆された。これらの結果は, 筆者らが既に報告しているリバーレッド ガム (Eucalyptus camaldulensis)の密度効果実験の結果と矛盾しなかった.

4. 本研究で用いた 2 種の生長は, ストローブマツ(Pinus stobus), スギ (Cryptomeria japonica), ヒノキ (Chamaecyparis obtusa) などの温帯造林樹種に比べ非常に速い生長を示し，植栽後 6年の現存量はタイワンセンダンで49〜 87t/ha，インドセンダンで9〜 50t/haとなった.

5. 穂積モデルは, 初期密度, 実現密度, 個体重, 時間の4変数間の関係を同時に決定する ことができるモデルで，熱帯で用いられている多様な造林樹種の成長特性の比較に有効である と考えられた。 